\title{
Tre Sonderjyder i den danske Kunst.
}

Biografiske Skitser af H. R. Baumann.

\section{Christoffer Vilhelm Eckersberg.}

Garnisonskirken ude ved St. Anna Plads deler ydre Kaar med de fleste andre Kirker i Kjøbenhavn; manglende enhver arkitektonisk Slijønhed er den ude af Stand til at paadrage sig Nogens Opmærksomhed. Og dog standser de Forbigaaende ofte ved Gitteret for at betragte et Broncerelief, der er indsat i Kirkens Mur og forestiller en aldrende Kunstner red sit Arbejde.

Relieffet er et lidet Mindesmærke orer Christoffer Vilhelm Eckersberg, en af Danmarks største Kunstnere. Havde han ræret Søn af et støre Land, var Mindesmærket vel blevet anseeligere og tillige en Prydelse for dets Horedstad. Herhjemme maa vi som oftest nøjes med det mindre, skjøndt det større rettest vilde være paa sin Plads.

Som Dreng færdedes Christoffer Vilhelm Eckersberg red Sundeveds smilende Kyst i Nærheden af Landsbyen Blans i Ullerup Sogn. Derhen var han flyttet med sine Forældre fra Blaakrog i Varnæs Sogn, hror han var født den 2den Januar 1783. Faderen var foruden Snedker tillige Maler og skal ikke have manglet Erner som saadan; thi foruden at stryge Vægge og Døre dekorerede han Solhatte med smukke Rosenkrandse og nød Anseelse rerfor paa Egnen; men det, som hos ham kun var svage Spirer, skulde hos Sønnen udvikle sig til herlig Blomstring. 
Tidligt begyndte Sønnen at gaa sin Fader i Næringen, og en hrid Kat samt en Baad, der er trukken paa Land, hvormed han havde prydet Væggen i sine Forældres Stue, vakte især hans Kammeraters udelte Beundring. Naturligt var det derfor, at Faderen satte Drengen i Malerlære; forst sendtes han til Aabenraa og senere til Flensborg, hvor han blev til sit tyvende Aar. I denne By fandtes endnu for et halvt Aarhundrede siden en Disk i en Kjobmandsbod, som Eckersberg havde dekoreret med Landskaber; den er forlængst bleven aflost af en "finere" $0 \mathrm{~g}$ senere fuldstændig forsvunden; Lrræmmeren havde jo ikke bedre Forstand. Men i Begyndelsen af Aarhundredet fandtes der i Flensborg heldigvis Hænd, som havde For'stand paa, at den unge Malersvend forstod mere end at stryge en Dør, og derfor gjorde Udveje til, at han kunde komme ind paa Kunstakademiet i Kjøbenharn.

Derhen rejste han 1803, og om han end rar nodt til i de første Aar at ernære sig som Malersvend, thi Understøttelsen fra Flensborg kunde ilke strække til, gjorde han dog paa Akademiet saa hurtige Fremskridt, at han i 1805 ikke blot vandt begge Solvmedailler, men ogsaa den lille Guldmedaille, som tilkjendtes ham for Opgaven „Paulus som retfærdiggjør sig for Agrippa, Berenice og Festus", og 1809 vandt han den store Guldmedaille for „Jakobs Død“. Abildgaard var den Gang Direktør for Akademiet; han viste den unge Kunstner særlig Interesse, og man sporer tydelig hans Indfydelse paa Eckersbergs Arbejder fra denne Tid.

Malerhaandværket kunde vor unge Tunstner heldigvis opgive, da han ved at udføre Tegninger for Kobberstikkerne Clemens og Lahde kunde fortjene det, han behøvede til 
Livets Ophold. For Clemens udførte han seks Tegninger til den bekjendte Suite Kobberstik „Skomager'srendens Historie eller det store Lod“ og fire Tegninger til „En falden Piges Historie“, og for Lahde en Række Tegninger med Emner fra Eng]ændernes Overfald 1807 og Kjøbenhavns Bombardement. Desuden malede han i disse Aar flere storre og mindre historiske Kompositioner foruden en Del Landskaber.

Uagtet Eckersberg i 1809 havde vundet den store Guldmedaille, kunde Stipendiet dog ikke urbetales ham før i 1812. Gode Venner skaffede derfor Midler tilveje, saa at han allerede den 3die Juli 1810 kunde rejse til Paris, hvor han forblev indtil Sommeren 1813. Efterat være bleven mere fortrolig med det franske Sprog, opmaade han en Plads par Revolutionens beromte Malers, Louis Davids Atelier. Dette Ophold blev af stor Betydning for Eckersberg, der paavirkedes stærkt af Davids sikie Tegning, klare, lyse Farver og Kjærlighed til Naturen, derimod mindre af hans historiske Stil og Liniernes Strenghed. Paavirkningen foles i det til Horne Kirke ved Faaborg udførte Alterbillede „Kristus, som lader de smaa Børn komme til sig“, og i det store Billede paa den kgl. Malerisamling „Moses lader det røde Hav træde tilbage og Pharaos Hær oversvømmes", hvilket Arbejle fuldførtes i Rom.

Til deme By rejste Eckersberg den 5te Juni 1813 fra Paris med en Veturin. Rejsen var meget fornøjelig, og i sine Breve fortæller han livfuldt om sit Rejseselskah, af hvilket "den behagelige" Signora Neri, der havde været ansat ved Operaen i Paris, især syntes at have gjort Indtryk paa ham. 
I Rom fandt han en trofast Ven i Thorvaldsen, og med hvilken beundrende Kjærlighed Eckersberg har set op til sin berømte Landsmand, spores bedst i det kostelige Portrait, som han har malet af ham under sit Ophold i den evige By. Nu hænger Billedet i Kunstakademiets Festsal paa Charlottenborg og er jo ligesaa bekjendt som berømt, men vi kunne dog ikke undlade at gjenkalde i Læserens Erindring de vidunderligt tegnede Hænder, det skjønne Hoved og fremfor Alt dette Blik, gjennem hrilket den store, mægtige Aand, som iboede denne herlige Skikkelse, aabenbarer sig. Jo oftere man ser dette Billede, desto stærkere betages man af det, og man fristes til at sige, at der i Danmark aldrig er malet et skjønnere Portrait.

Under sit Ophold i Rom udførte Eckersberg tillige en hel Række Prospekter af Byen og dens maleriske Omegn, der vel nærmest maa betragtes som Studier, men som paa Grund af den omhyggelige Tegning og fine Farvetone skattes højt.

I August 1816 vendte Eckersberg tilbage til Kjøbenhavn og blev den følgende Maaned agreeret til Akademiet. Til Medlemsarbejde fik han Opgaven „Balders Død“, men dette Arbejde optog ham saa længe, at han forst den 25de Oktober 1817 kunde optages som Medlem af Akademiet. Samme Aar, i Februar Maaned, havde han ægtet Elisabeth Cathrine Julie Juel, en Datter af ror bekjendte Portraitmaler Jens Juel.

Abildgaard var jo allerede død i 1809; men den red hans Død ledigblevne Professorplads var ikke bleven besat, uagtet der havde været Ansøgere nok om den. Man rentede paa den rette Mand, og denne blev funden, da Eckersberg den 18de April 1818 enstemmig bler valgt til Professor. 


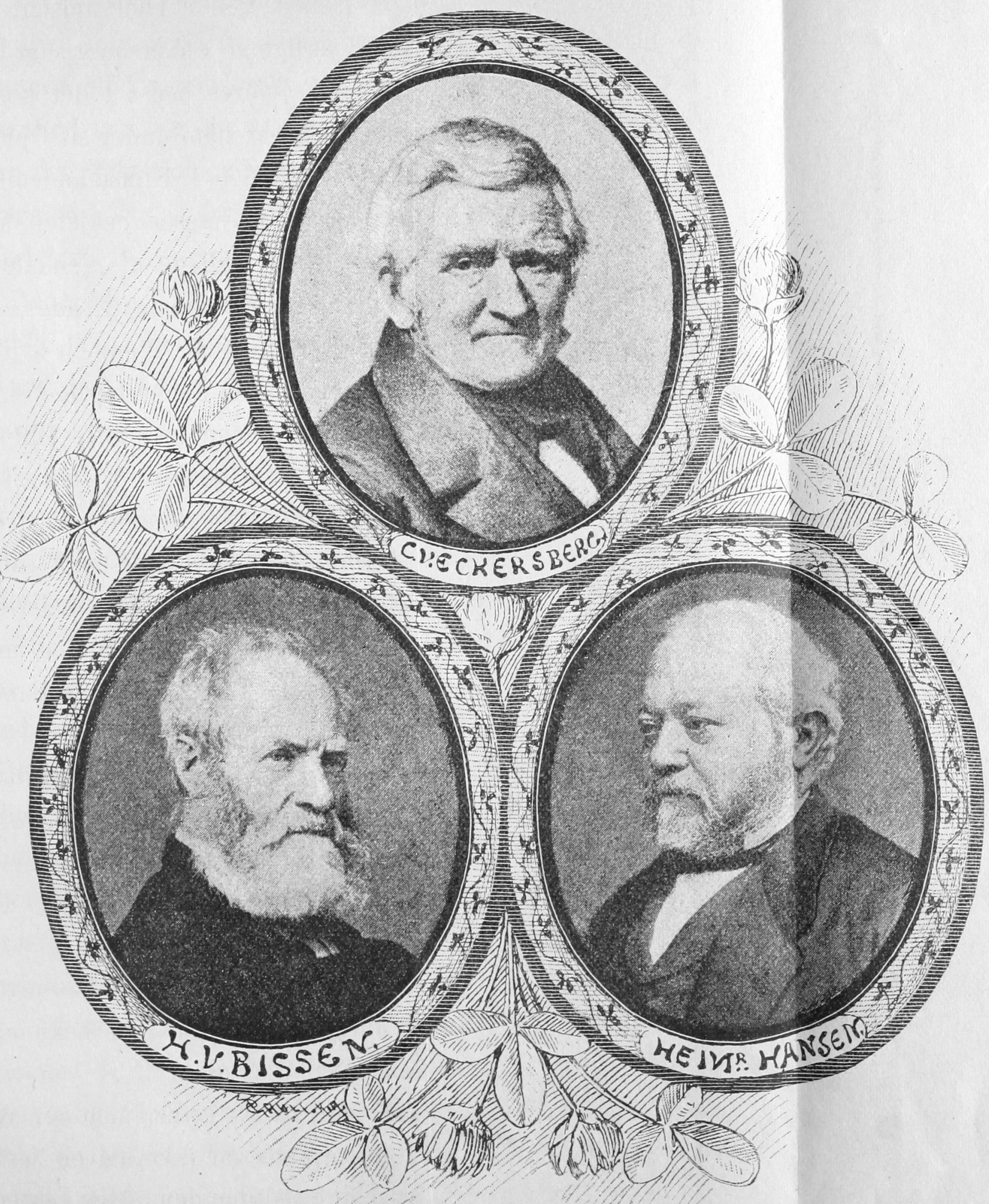


Den nye Professor flyttede ind paa Charlottenborg, og den Alsidighed o $g$ udmærkedle Dygtighed, hvormed han røgtede sit Embede, blev af den største Betydning for den danske Kunst og de danske Kunstnere; thi for Eckersberg var det ikke nok selv at være Kunstner, han vilde ogsaa gjore sin Kunst frugtbringende. $\mathrm{Og}$ denne Opgave forstod han at løse paa en Maade, som kun Faa har ræret i Stand til. Talrig var Antallet af hans Elever, blandt hvilke kan nærnes Mænd som Bendz, Køøke, Küchler, Marstrand, Adam Müller, Roed, Skovgaard og Lundbye, Iænd, hvis Arbejder staa som straalende Stjerner paa den danske Kunsthimmel; men Eckersberg forstod at lade enhver af dem udvikle sig selvstændigt, han hørte ikke til de Lærere, der forlange, at Eleverne slavisk skulle efterligne deres Mester. Men samtidig med, at Eleverne fik Lov til at udvikle deres eget Kunstnernaturel, kunde de ikke undgaa at paavirkes af Læererens varme Kjærlighed til Naturen, aabne Sands for Virkeligheden, sanddru Gjengivelse af det Sete og at tilegne sig den Skarphed $\mathrm{i}$ Omridsene og Fasthed i Modelleringen, der var saa ejendommelig for Hesteren. Stor var Eckersberg som Kunstner, men man kunde næsten fristes til at anse ham for endnu større som Lærer; thi som saadan blev han Fader til den. nationale Kunst i Danmark.

Optoges Eckersberg nu end meget af denne sin Virksomhed ved Akademiet, fandt han dog Tid til at male en betydelig Række udmærkede Portraiter, blandt hvilke vi som de lettest tilgjængelige blot ville nævne det Nathansonske Familiebillede paa den kgl. Malerisamling og Frederik VI med sin Dronning og sine Døttre paa Rosenborg. Desuden udførte Eckersberg mange Historiebilleder 
og Altertavler. Blandt de første udmærke de otte store Malerier til Kristiansborg med Emner fra de oldenborgske liongers Historie sig ved deres historiske Troskab og Følelse for Natursandhed, men man føler tillige, at den Kommission, som har givet Opgaven, har forstaaet sig bedre paa Fædrelandshistorien end paa, hvorvidt de opgivne Emner egnede sig til kunstnerisk Behandling. Derred har den paa Kunstneren lagt et Baand, hvis hæmmende Virkning spores i Arbejdet.

I Altertavlerne lægger Eckersberg som oftest en smuk religiøs Følelse og fin psykologisk Sands for Dagen, men paa Grund af disse Arbeiders Talrighed kan man ikke undres over, at nogle af dem ere lidt matte i Virkningen og smaalige i Udforelsen. Som de betydeligste kunne nævnes „Kristus i Gethsemane“ (Svendborg), „Kristus og den samaritanske Kvinde“(Hornbæk) og „Bjergprædikenen“ (Nyborg).

Fremgaar allerede af Ovenstaaende Eckersberg store Alsidighed, kunde man dog fristes til at fremhæve hans Virksomhed som Sømaler som den betydeligste, ja man kan med Rette kalde ham Skaberen af det danske Sømaleri.

Spiren hertil blev sikkert lagt, da han som Dreng færdedes ved Sundeveds smilende Strande og ofte fulgte Faderen paa Fisketoure i Aabenraa Fjord og Alssund. Tidligt modtog han her Indtryk af den store, frie Natur, af Sø og Luft, Solnedgang og Blæst. Paa Væggen i Forældrenes Stue var jo Emnet til hans tidligste Maleri „En Baad trukken op paa Land". Denne Kjærlighed til Havet var ham indpodet fra Ungdommen af, dog ikke til det store, vilde Hav, men til den milde, fredelige Sø mellem 
vore Øer. Derfor henter han ogsaa sine Motiver væsentlig fra Øresund, udenfor det gaar han sjældent; men indenfor dette mindre Omraade hersker han med overlegen Souverainitet.

Eckersberg Virksomhed som Sømaler kan man dele i tre Perioder. I Billederne fra 1821-28 er Penslen blødere, Farven kraftigere og varmere end i de følgende. I Tiden fra 1829-38 aabenbarer sig en skjonnere Tegning, en finere, grundigere Udførelse af Skibene, en fortrinlig Fordeling af Planerne, men tillige en koldere Farve. Som Arbejder fra denne Periode ville vi fremhæve „Et russisk Linieskib" og "Linieskibet Dronning Marie“ paa den $\mathrm{kgl}$. Malerisamling og det i Privateje værende Arbejde, hvortil Emnet er hentet fra Ewalds „Fiskerne“ og hvis Titel er „Fiskere fra Hornbæk, som fra et indstrandet Skib have reddet og ilandbragt Skilsføreren, den sidste tilbageblevne af Besætningen". Billedet er kun lilie, men virker saa storladent ved den alvorlige Naturscene, ved sine kraftige Linier, ved de skummende Bølgekamme, drivende Skyer og ved de med Helheden udmærket samstemmende Figurer.

Til ligefrem Mesterskab hæver Eckersberg sig i Søbillederne fra 1839-48, og man forbauses over Farvens Dybde og Kraft, over det glimrende Perspektiv og over Blødheden i Bølgernes Bevægelse. Mange Arbejder fra denne Periode kunde nævnes, men ligesom ovenfor ville vi anføre de lettest tilgjængelige, nemlig „Parti af Øresund“ og "Parti af Kjøbenhavns Rhed" paa den kgl. Malerisamling.

Efter 1848 aner man, at Kunstneren nærmer sig Støvets Aar; Øjet er svækket og Haanden usikker; maa 
man end stedse anerkjende selv i de seneste Arbejder Skibenes smukke Bevægelse og Bølgernes forskjellige Karakter, føler man dog, at Timeglasset snart er udrundet. Men var Evnen end svækket, var Kjærligheden det ikke; det sidste Arbejde den famlende Haand syslede med, var et Søbillede. Den 22de Juli 1853 drog den store Kunstner sit sidste Suk, et Bytte for den Byen hærgende Koleraepidemi.

Er det Mindesmærke, Samtiden har rejst over Christoffer Vilhelm Eckersberg kun uanseligt og lidet, saa er det Minde, han har rejst sig selv i den danske Kunst, desto større.

\section{Herman Vilhelm Bissen.}

Ved Kanalen, ligeoverfor Arsenalet, ligger en lav, uanselig Bygning, næsten fattig af Y'dre, som en Fremmed næppe vilde skjænke et Blik, end sige en Tanke, men som for os Danske ligger omstraalet af Mindets Glorie. Bag dens lave Mure lød Mejslens Klang i det skjønne, hvide Marmor, under dets gamle Tag rejste sig i det vaade Ler de herligste Værker, kaldede til Live af den Genius, som var Hersker derinde, og hvis Navn var Herman Vilhelm Bissen.

Ogsaa han var en Sønderjyde, helt nede fra den gamle Slesvig By, hvor han saa Lyset den 13de Olitober 1798. Sin Barndom henlevede han dels dér dels i det smukke Angel, og da han alt som Dreng viste kunstneriske Evner, blev han i sit attende Aar sendt til Kjøbenhavn for paa Kunstakademiet at uddannes som Maler, og som saadan vandt han den lille Sølvmedaille 1819. Lysten til at blive 
Billedhugger var imidlertid vaagnet, og da han 1821 vilde konkurrere til den lille Guldmedaille, tog han begge Fags Redskaber med sig; han var ikke paa det Rene med sig selv, hvilken Tej han skulde vælge. Et Tilfælde -- hans Farvespatel knækkede - afgjorde Spørgsmaalet for hele Livet; han udførte Opgaven „Josefs Brødre vise Jakob hans Søns blodige Kjortel“" som Relief og fik Medaillen. To Aar efter vandt han den store Guldmedaille for "Jairi Datter" og opnaaede derved Retten til Akademiets store Rejsestipendium.

I Rom traf Bissen Thorvaldsen, som den Gang stod par Berømmelsens Tinde, men han ligesom ikke vovede at nærme sig frimodigt den store Mester, hvis Værker han dog beundrede saa højt, han følte sig selv saa ringe. Denne Tilbageholdenhed, der havde sit ædleste Udspring, blev udlagt som Stolthed og Sliinsyge, og der hengik nogen Tid, inden Thorvaldsen lærte at skatte Bissen baade som Menneske og Kunstner; men da Isen først var brudt, blev Venskabet desto inderligere. Med Varme sluttede han sig ogsaa til den noget ældre danske Billedhugger Herman Ernst Freund, og i Rom begyndte et Samliv, der fortsattes paa den skjønneste Maade efter begges Hjemkomst til Danmark.

Under sit første Ophold i Italien, der varede omtrent ni Aar, udførte Bissen allerede flere Arbejder, saasom „Belisar", „Blomsterpigen“, Relieffet „Kristus vadsker Apostlenes Fødder", der vakte fortjent Opmærksomhed, men det var dog først efter Hjemkomsten i 1834, at Bissens Geni udviklede sig i hele sin Herlighed.

Som Medlemsarbejde (1835) udførte han den fine, yndefulde "Valkyrie“, og i den store Frise „Bacchus og 
Ceres bringe Menneskene Kulturens Gaver“, der udførtes til Riddersalen paa Kristiansborg, aflagde han en glimrende Prøve paa den Friskhed, hvormed han forstod at behandle Emner fra den græske Oldtid. Fra nu af roksede hans Virksomhed i forbausende Grad; Slag i Slag fremstod det ene betydelige Arbejde efter det andet. Nede i det store Atelier havde de talrige Elever, der ikke blot fra Danmark, men ogsaa fra Norge, Sverige og fremmede Lande strømmede til for at lære hos den store Kunstner, fuldt op at gjøre med at arbejde efter Mesterens Udkast eller udføre de færdige Modeller i Marmor. I det mindre Atelier oppe under Taget, foran hvis brede Vindue Cypresser og Palmer voxede i yppig Fylde, hvor store italienske Edderkopper spandt deres gyldne spind mellem barokformede Kaktus, hvor Firben vimsede om mellem Planternes Grene, hvor Vagtler og smaa Skildpadder opsøgte de varme Solstraaler, dér færdedes Bissen alene og lod af det vaade Ler de Tanker, der fyldte hans Sjæl, rejse sig til Liv i uforlignelig Skjønhed.

Paa dette stille Sted saae „Orest“ Lyset. Efter Oraklets Befaling har han dræbt sin Moder for at hævne Faderen; med det bloddryppende Sværd begiver han sig til Raadet for at fortælle sin Daad, da viser sig pludseligt Moderens Hævngudinder med truende Slangesvøber, og i navnløs Rædsel iler han bort. Denne grændseløse, sjælelige Angst har Bissen forstaaet at give med samme Mesterskab som Udtrykket for den legemlige Lidelse i „Filoktet", der ikke vover at sætte den af Herakles forgiftede Pile ulægelig saarede Fod fast ned mod Jorden; krampagtig støtter han sig til Buen, medens hans anden Haand fortvivlet omklamrer Koggerets brede Baand foran Brystet; hver Muskel 
i det stolte Legeme bærer i Smerte. Og hror herlig er ikke "Achilles" i sin Harme og Sorg over, at man har frarøvet ham den elskede Briseis.

Med aldrig svigtende Sikkerhed forstaar Bissen i hvert enkelt Tilfælde at give netop det, som det kommer an paa. Den ophøjede Ro i „Apollo“ og „Ninerva“, Myndigheden i „Moses“, Højheden i „Kristian IY“, Selvsikkerheden i "Tyge Brahe“, Kjækheden i „Tordenskjold", den digteriske Beaandelse i „Oehlenschlæger“" Jevnheden og Arligheden i „Frederik VI“, det Folkelige, Vennesæle i „Frederik VII.“

Bissens Buster ere hartad vidunderlige og orergaa næsten Thorvaldsens; saa fine i Folelsen, saa sjælfuldt opfattede, saa talende i Udtrykket, saa fuldendte i Formen.

Fortrinlige ere ogsaa de ædle Kivindeskikkelser, hrormed Bissen smykkede Dronmingens Trappe paa Kristiansborg. Bestillingen lød paa atten Statuer, men hvor sindrig. har Bissen ikke løst denne Opgave. Blandt Danmarks Dronninger valgte han den ædle Thyra, den fromme Dagmar, den statskloge Margrethe og den heltemodige Philippa. Til de andre fjorten valgte han Kvinder, som de græske Digtere og de nordiske Sagn have foreviget. At nævne dem alle, er ikke her paa sin Plads, kun fremhæve enkelte for at vise, med hvilket Snille Bissen forstod at finde Pendanter i de forskjellige Sfærer. Den stolte Skjoldmø „Brynhilde“, hrem Sigurd elskede, og den modige Amazone „Antiope“, som vandt Theseus Kjærlighed; „Gudrun" overvældet af Sorg over Sigurds Død og „Andromache“, der ser Hektor ile til den for ham saa skjæbnetunge Kamp; "Alkestis“, der frivilligt gik i Døden for at frelse sin Husbond, Kong Admetos, og "Nanna“, hvis Hjerte brister, idet Balder lægges paa Baalet. 
Da der skal rejses et Mindesmærke i Anledning af Slaget ved Fredericia, vælger Bissen ikke den kommanderende General omgiven af sine krigskyndige Officerer, saaledes som man saa ofte ser lignende Monumenter i Udlandet; han tager den menige Soldat, der jublende svinger en frisk Bøgegren, medens Foden træder paa et Stykke erobret Skyts, og han giver" os derved et saa enkelt, men tillige saa veltalende Symbol paa Sejren. Men ved dette Arbejde var tillige en anden, en hel ny Opgave at løse, nemlig at fremstille en Sejerherre $i$ den tarvelige Soldaterdragt. Kunstneren kunde her ikke tye til alle disse, af tidligere Kunstnere saa ofte benyttede flatterende Biting, hvad enten de bestaa $i$ et romersk Imperatorkostume eller en flagrende Generalskappe og bølgende Fjer paa Hatten. Sligt havde Bissen iklie Behov for; ved uforbeholden at slutte sig til Virkeligheden formaaede han at give den prunkløse Soldaterdragt en ægte plastisk Karakter og Helheden en saa storladen Virkning.

Medens vi i "Landsoldaten" ser Jublen over Kampen for det elskede Fædreland, møder os i det store Relief over Heltegraven den dybe, smertelige Alvor, hvormed to Soldater bære den faldne Kammerat til det sidste Hvilested. Og saa den stolte "Løve“ paa Flensborg Kirkegaarcł - dog ved Mindet om den forsmædelige Skjæbne, der ramte dette Gravminde, krymper Hjertet sig smerteligt sammen.

Som Bissens Kunst, saa var han selv, ædel og sandru, trofast og elskelig. Derfor var Sorgen ogsaa stor, da Budskabet lød den 10de Marts 1868, at Døden havde kaldet ham bort fra hans rige Virken. Faa Dage efter var Antiksalen paa Charlottenborg draget med Sort, fra hvis mørke 
Baggrund Bissens mægtige Buste tavs skuede hen over de Mange, som med Kongehuset i Spidsen havde givet Møde. I en gribende Tale skildrede hans trofaste Ven, Professor Høyen, Bissen som Kunstner og Menneske og rejste ham i Ord et Eftermæle, der vil staa urokkeligt i de kommende Tider.

\section{Heinrich Hansen.}

Over ingen af Danmarks Konger hviler et saa ejendommelig romantisk Skjær som over Kristian IV, han er Folkets verdslige Helgen og tilbedes $i$ de af ham rejste herlige Bygninger, de skjønneste Danmark har i Eje. Hvem gribes ikke af den forunderlige Poesi, der hviler over Frederiksborg og Rosenborg, og hvor langt stærkere maatte saa ikke denne Skjønhed gribe en ung, for sit Kald varmt folende Kunstner. Men ligesaa stor hans Kjærlighed var til disse stolte Fortidsminder, ligesaa flittig var hans Haand til i talrige, fortrinlige Billeder at gjengive ikke blot disse Bygningers herlige Ydre, men ogsaa de prægtige Sale og Gemakker, de indesluttede. Udført i Farvetryk pryde disse Arbejder nu minge Hjem; at erhverve Originalerne er jo kun de Færreste forundt.

At nævne Kunstnerens Navn er jo egentlig overflødigt, vi vide jo alle, at han hedder Heinrich Hansen. Det er det "nom de guerre“, under hvilket han har erhvervet sine liunstneriske Laurbær, og med hvilket han stedse vil mindes.

Heinr. Hansen stammer fra Sønderjylland, og dette forstod man saa godt, naar man kjendte ham personlig. Hele hans Væsen var præget af denne Bonhomie, der er 
ejendommelig for Sønderjyden, og han omfattede sit Fødeland, efter at det var løsseret fra Moderlandet, med forstærket Kjærlighed. Han er født i Haderslev den 23de Novbr. $1821 \mathrm{og}$ kom som ungt Menneske i Malerlære i Flensborg, Forældrenes Fødeby. Ved dette Arbejde blev han fortrolig med Teknikken og med det for en Kunstner nødvendige Materiale, hvilket blev af stor Betydning for hans senere Virksomhed.

Fra Flensborg drog Heinr. Hansen 1842 til Kjøbenhavn, hvor han som Elev af Kunstakademiet uddannede sig til Dekorationsmaler og strax blev benyttet ved Udsmykningen af Thorvaldsens Museum. Hurtig efter hinanden vandt han Akademiets lille og store Sølvmedaille, den sidste endog to Gange, og tiltraadte 1847 med offentlig Understøttelse sin første Udenlandsrejse, der ræsentlig gjaldt Tyskland, fra hvilken han medbragte en Række Studier med Emner fra de mangfoldige, interessante Bygninger hos vore sydlige Naboer, og fra nu af dyrkede Heinr. Hansen ræsentlig Arkitekturmaleriet, paa hvilket Omraade han i Tidernes Løb er bleven Danmarks betydeligste Kunstner.

Paa gjentagne Rejser besøgte Heinr. Hansen saa godt som alle større europæiske Lande, og overalt fænoslede han til Lærredet de interessanteste Motiver, lige oppe fra Trondhjem og Skotland og ned til Spaniens og Italiens solrige Egne. At opregne her hele Rækken af den forbausende flittige Kunstners talrige Arbejder vilde være uorerkommeligt; men Enhrer, der jaculigt har besøgt rore Udstillinger, vil mindes hans Gjengivelser af belgiske Kirker, Alhambras Søjlegaarde, Dogepaladsets Pragtsale, af Kirker, Klostre, Paladser og Patricierhuse i Italien, Spanien, Frank- 
rig og mange andre Lande. Disse Arbejder tiltale ikke blot ved Valget af Motivet, men forbause tillige ved Udførelsen af samtlige Detailler og ved det fortrinlige Perspektiv; intet Under, at Heinr. Hansen alt tidligt blev knyttet til Akademiet som Docent i dette Lærefag, hvilket han beherskede som Faa. Vor Kunstners Arbejder ere gjennemgaaende af mindre Omfang, men at han ogsaa forstaar at tumle med store Masser, har han vist i sit Billede „Parti ved Gammelstrand“, der tilhører den kgl. Malerisamling, og i "Arvehyldningen paa Kjøbenhavns Slotsplads", som han udforte til Nationalmuseet paa Frederiksborg. Paa sine betydelige Evner som Dekorationsmaler aflagde han en glimrende Prøve ved at male de mægtige Sandstensrammer omkring Vilh. Marstrands herlige Billeder af Kristian IV Historie i denne Konges Gravkapel ved Roskilde Domkirke. Med Pensel og Farve har han paa Kapellets Væg fremkaldt et saadant Sandsebedrag, at mange Besøgende først ved at lægge Haanden paa den flade Mur kunne overbevises om, at Rammerne ikke ere udhuggede i virkelig Sandsten.

Det er dog ikke blot som Arkitekturmaler, at Heinr. Hansen indtager en fremragende Plads, ogsaa hans Virksomhed for at hæve og udvikle det danske Kunsthaandværk er af allerstørste Betydning. En rig Anledning hertil frembød Gjenopførelsen af Frederiksborg Slot. Faa vare jo saa fortrolige med denne herlige Bygnings mindste Detailler som Heinr. Hansen, og derfor var han fremfor nogen Anden i Stand til at give nøjagtige Tegninger til de Rum, der skulde gjenopføres i deres oprindelige Skikkelse, saasom Riddersalen, Rosen og Bedestolen. At arbejde efter disse Tegninger rar af stor Betydning for de derved be- 
skjæftigede Haandværkere, de lærte mangt og meget, der vil bære Frugt i Fremtiden. Men ogsaa paa andre Omraader blev det Heinr. Hansen forundt at virke til Gavn for det danske Kunsthaandværk. Det var nemlig ham, hvem Oprettelsen af "Kunstflidslotteriet" skyldtes, hvis Formaal var gjeunem Bortlodning af Kunstflidsgjenstande at tilvejebringe Midler til Slottets Gjenopforelse, og red denne sin Virksomhed, til hvilken han forstod at knytte rore betydeligste Kunstnere, er det lykkedes ham at forædle Smagen blandt Haandværkere og Publikum.

Rig og betydningsfuld har hans Virksomhed været. Intet Under derfor, at vort Lands Konge paa forskjellig Maade, ved Udnævnelse til Etatsraad og Tildeling af høje Ordensdekorationer har hædret ham, ligesom ogsaa udenlandske Fyrster paa lignende Maade have vist ham deres Anerkjendelse. Kunstnernavnet "Heinr. Hansen" vil dog: overleve alt dette.

I den unge Kunstners Sjæl tændtes en beundrende Kjærlighed til Kristian IV og hans skjønne Værker, og denne Kjærlighed slukkedes aldrig. Vi skylder Heimr. Hansen, at Neptun-Fontainen atter rejstes i Frederilssborgs ydre Slotsgaard - Midlerne hertil skjænkedes jo af en Mand, hvis Navn altid vil mindes med Taknemmelighed af det danske Folk - og endnu syslede Heinr. Hansen med Arbejder til Fuldendelsen af det skjøme Slot ved den skovomkrandsede Indsø, da Døden mildt kaldte ham bort den 11te Juli 1890. 